\title{
PEMENUHAN ASAS TRANSAKSI SYARIAH PADA PEMBIAYAAN DENGAN AKAD MURABAHAH
}

\author{
Muhammad Daud bin Mahmud \\ Fakultas Ekonomi dan Bisnis Islam, Institut Agama Islam Negeri Ternate \\ Jalan Lumba-Lumba No. 8, Ternate, Maluku Utara, 97727, Indonesia
}

Corresponding Author:

Nama Penulis: Muhammad Daud bin Mahmud

E-mail: daud@iain-ternate.ac.id

\begin{abstract}
This study aimed to determine the flow of the financing processes with murabahah contract at Bank Syariah Mandiri Branch Office Ternate and to exam whether the financing practices are in accordance with the principles of sharia transactions as stated in Standar Akuntansi SyariahIndonesian Accounting Standard Board by using qualitative method. The data were collected by using the triangulation sources approach by interviewing a competent banker and a customer, then the results of the interviews are compared with related regulations. The results of this study proved that procedurally the financing processes at Bank Syariah Mandiri Branch Office Ternate has fulfilled the sharia principles, but practically the principle of justice in murabahah contract can not be fulfilled.
\end{abstract}

Keywords: Murabahah; Bank Syariah Mandiri; Sharia Principles

\begin{abstract}
Abstrak
Tujuan penelitian ini adalah untuk mengetahui alur proses pembiayaan dengan akad murabahah di Bank Syariah Mandiri Cabang Ternate dan memastikan apakah praktik pembiayaan tersebut telah sesuai dengan asas transaksi syariah sebagaimana yang tertuang dalam Standar Akuntansi Syariah-Ikatan Akuntan Indonesia. Penelitian ini menggunakan metode kualitatif. Pengumpulan data penelitian menggunakan pendekatan triangulasi sumber dengan mewawancarai pihak bank dan nasabah kemudian hasil wawancaranya dibandingkan dengan peraturan terkait. Hasil penelitian ini membuktikan bahwa secara prosedural, alur proses pembiayaan di bank Syariah Mandiri Cabang Ternate telah memenuhi prinsip syariah tetapi secara praktiknya asas keadilan dalam transaksi pembiayaan dengan akad murabahah belum bisa dipenuhi.
\end{abstract}

Kata kunci: Murabahah; Bank Syariah Mandiri; Asas Transaksi Syariah 


\section{PENDAHULUAN}

Perbankan syariah di Indonesia terus mengalami pertumbuhan, mulai dari jumlah kantor Bank Umum Syariah (BUS) yang terus bertambah menjadi 14 BUS di Tahun 2018 sampai dengan total asetnya yang terus mengalami peningkatan (Otoritas Jasa Keuangan, 2019). Meskipun perbankan syariah di Indonesia terus mengalami pertumbuhan, keraguan konsumen terhadap kehalalan produk yang ditawarkan bank syariah masih dipersoalkan (Ahmed, 2014; Rahmayati, 2018; Sukardi, 2012). Prinsip syariah yang diimplementasikan oleh perbankan syariah nyatanya masih belum ideal (Mukhibad, 2018). Bank syariah masih dipersepsikan sama dengan bank konvensional dari segi produk meskipun terdapat perlakuan khusus pada produk bank syariah (Ekawati \& Shofawati, 2019; Malik et al., 2011). Munculnya keraguan konsumen terhadap bank syariah ini diakibatkan oleh praktik satanic finance yang masih dipraktikan oleh beberapa pihak internal bank syariah dalam menjalankan aktivitas operasionalnya (Wahyuni, 2018).

Dari semua produk yang ditawarkan bank syariah, murabahah adalah produk yang paling diminati oleh nasabah (Mardian, 2015; OJK, 2016, 2019). Meskipun mendominasi produk pembiayaan perbankan syariah, murabahah ternyata bukan merupakan instrumen pembiayaan utama jika dibandingkan dengan mudharabah dan musyarakah di dalam hukum islam. Murabahah dijadikan alternatif pembiayaan oleh beberapa ulama kontemporer karena terdapat kesulitan dalam penerapan mudharabah dan musyarakah pada beberapa sektor pembiayaan (Pardiansyah, 2017).

Murabahah yang dipraktikan di perbankan syariah saat ini telah banyak mengalami perubahan, bahkan ada yang menilai bahwa praktik tersebut menyimpang dari konsep dasar murabahah dalam islam (Lathif, 2013; Mardian, 2015; Maulana \& Rozak. 2021). Jenis murabahah yang dipraktikan oleh sebagian besar bank syariah saat ini, sebagaimana fatwa Dewan Syariah Nasional-Majelis Ulama Indonesia (DSN-MUI) tentang akad jual beli murabah, yaitu murabahah Bai' al-murabahah li al-amir bi al-syira' (Prabowo, 2009). Murabahah jenis ini membolehkan bank sebagai penjual untuk memesan barang yang dipesan oleh nasabah untuk kemudian diserahkan kepada nasabah dengan menyatakan margin dari penjualan barang tersebut.

Selain fatwa DSN-MUI, dalam Peraturan Bank Indonesia No.9/19/PBI/2007 disebutkan bahwa pada praktik jual-beli dengan akad murabahah, bank syariah bertindak sebagai penyedia dana (Bank Indonesia, 2007). Dalam hal bank syariah bertindak sebagai penyedia dana, ia dapat menyerahkan sejumlah uang dan diikutkan dengan mendelegasikan wewenangnya sebagai penjual kepada nasabah (pembeli) sehingga nasabah 
berhak menggunakan uang tersebut untuk mendapatkan barang yang dibutuhkan atas namanya.

Dari 14 laporan keuangan BUS tahun 2019, Bank Syariah Mandiri (BSM) memiliki jumlah pembiayaan murabah paling banyak yakni 40,1 triliun rupiah. Pertumbuhan pembiayaan bank syariah di Maluku Utara tercatat sebesar 16,38\% pada triwulan IV 2019 (BI, 2020).

Pembiayaan yang dilakukan bank syariah di Maluku Utara, khususnya pembiayaan modal kerja, tercatat mengalami peningkatan cukup signifikan di tahun 2019. Di Kota Ternate terdapat dua BUS namun dari laporan tahunan kedua bank tersebut di Tahun 2019, BSM memiliki total pembiayaan paling besar yakni 99 Triliun dibanding Bank Mualamalat Indonesia (BMI) yang hanya 29 Triliun (BMI, 2019; BSM, 2019).

Dengan besarnya capaian distribusi pembiaayaan BSM di atas, kemudian muncul pertanyaan, apakah proses pendistribusian pembiayaan di BSM Cabang Ternate telah sesuai dengan asas transaksi syariah sebagaimana yang telah ditetapkan oleh DSN-MUI atau terdapat praktik satanic finance sebagaimana yang dikemukakan oleh Wahyuni (2018) bahwa praktik pembiayaan di beberapa bank syariah masih belum sesuai dengan kaidah pembiayaan dalam hukum islam.

\section{KAJIAN PUSTAKA}

\section{Bank Syariah}

Bank syariah, sebagaimana didefinisikan dalam UU Nomor 21 Tahun 2008, adalah bank yang seluruh kegiatan operasionalnya dilandaskan pada prinsip syariah. Dalam undang-undang tersebut yang dimaksud dengan prinsip syariah adalah prinsip hukum islam dalam kegiatan perbankan yang difatwakan oleh Majelis Ulama Indonesia. Prinsip inilah yang menjadikan bank syariah berbeda dengan bank konvensional.

Bank syariah berbeda dengan bank konvensional dari segi fungsi. Bank konvensional hanya berfungsi sebagai lembaga intermediasi dan penyedia jasa keuangan sementara bank syariah selain memiliki fungsi sebagai lembaga intermediasi dan penyedia jasa keuangan juga menjalankan fungsi manajer investasi, fungsi investor, dan fungsi sosial (Harahap et al., 2010). Jika bank konvensional dioperasikan berlandaskan pada prinsip bunga maka bank syariah dioperasikan berlandaskan pada prinsip bagi hasil, jual beli dan sewa sebagai imbal hasil (Pardiansyah, 2017).

Perbedaan bank syariah dan bank konvensional juga terlihat pada aspek legalitas. Setiap kontrak yang dilakukan dalam perbankan syariah harus memenuhi aspek legal seperti rukun dan syarat kontrak (akad). Salah satu aspek legal yang menjadi ciri bank syariah adalah syarat untuk barang yang ditransaksikan. Setiap barang yang menjadi objek akad harus terbebas 
dari unsur haram, harganya harus jelas, dan sepenuhnya dalam kepemilikan penjual (Anshori, 2018).

Dari aspek struktur organisasi bank syariah memiliki Dewan Pengawas Syariah (DPS) yang posisinya setingkat dewan komisaris dalam setiap struktur organisasi bank. Tugas DPS adalah untuk memastikan kepatuhan terhadap prinsip syariah dalam setiap kegiatan operasional dan produk yang digunakan oleh bank syariah. Keberadaan DPS merupakan ciri pembeda yang paling dominan antara bank syariah dengan bank konvensional.

\section{Murabahah}

The Accounting and Auditing Organisation for Islamic Financial Institutions (AAOFI, 2015) mendefinisikan murabahah sebagai penjualan suatu komoditas sesuai harga pembelian dengan menambahkan (mark-up) keuntungan yang telah ditentukan dan disepakati. Secara substansi, definisi tersebut sama dengan definisi dalam fatwa DSN-MUI (2017) bahwa adalah akad jual beli suatu barang dengan menegaskan harga beli barang tersebut kepada pembeli untuk kemudian dibayar olehnya dengan harga lebih.

Murabahah merupakan salah satu produk bank syariah dalam bidang penyaluran dana dengan prinsip jual beli. Suatu transaksi jual-beli dengan akad murabahah dapat dilakukan jika bank sebagai penjual telah memiliki barang yang akan diperjualbelikan secara hak sebelum barang tersebut dijual kepada calon pembeli atau nasabah. Hak kepemilikan atas barang oleh bank menjadi syarat mutlak sahnya suatu akad murabahah bai' al-murabahah al'adiyyah (DSN-MUI, 2017).

Murabahah berbeda dengan pinjaman (loan) secara prinsip. Untuk membedakan hal tersebut, Iqbal \& Mirakhor (2011), Hakim \& Anwar (2017) menjelaskan bahwa dalam murabahah tidak ada pinjaman berbentuk uang tetapi suatu aset dibeli untuk memastikan kepada nasabah bahwa pembiayaan yang dilakukan terikat dengan aset yang dibeli. Hal ini sejalan dengan norma islam bahwa pada prisipnya uang adalah alat tukar dan tidak dapat dijadikan sebagai komoditas (Kusuma, 2020; Ilmi, 2020).

Murabahah terdiri dari dua jenis yaitu murabahah biasa (ordinary murabahah) dan murabahah perbankan (banking murabahah) (AAOFI, 2015). Murabahah biasa adalah murabahah tanpa pesanan pembelian, artinya ada atau tidaknya calon pembeli, bank syariah tetap menyediakan barang sementara murabahah perbankan adalah murabah dengan pesanan pembelian, artinya akad jual beli akan dilakukan jika ada calon pembeli yang melakukan pesanan pembelian (Harahap et al., 2010; Nurdin \& Jariah, 2021).

Pada praktiknya, akad murabahah di BSM dapat digunakan untuk keperluan bisnis seperti pembiayaan modal kerja, pembiayaan untuk tujuan investasi, dan pembiayaan untuk keperluan konsumsi. Pembiayaan ini 
bertujuan untuk memenuhi kebutuhan para individu dan lembaga yaitu menggunakan akad murabahah (Zakiy \& Athief, 2015). BSM juga telah mengaplikasikan akad murabahah untuk memfasilitasi kebutuhan multiguna dan pembiayaan umrah serta pembiayaan untuk kepemilikan emas.

\section{Pemenuhan Prinsip Syariah (Sharia Compliance)}

Fungsi kepatuhan dalam perbankan adalah sebagai langkah preventif untuk memastikan bahwa semua aktivitas yang dilakukan dalam kegiatan operasional bank telah patuh terhadap peraturan yang berlaku. Maksud kepatuhan terhadap prinsip syariah adalah adanya kepastian bahwa setiap kebijakan, prosedur, dan kegiatan usaha yang dijalankan oleh bank syariah telah sesuai dengan peraturan perundang-undangan yang berlaku atau hukum positif dan telah sesuai dengan prinsip syariah atau hukum islam (Fauzia, 2018; Lestari \& Purbasari, 2019).

Prinsip syariah, sebagaimana definisi bank syariah dalam UndangUndang Nomor 21 Tahun 2008, adalah norma-norma islam yang wajib dipatuhi dalam praktik perbankan syariah yang mana setiap praktiknya harus bebas dari bunga, bebas dari kegiatan spekulatif, bebas dari kegiatan yang tidak jelas, bebas dari kegiatan yang sia-sia, dan semua kegiatan yang menjadi objek pembiayaan bank syariah harus memenuhi unsur halal (Anshori, 2018; Rohmaniyah, 2019).

Setiap transaksi di bank syariah dapat dinyatakan patuh terhadap prinsip syariah jika memenuhi asas-asas transaksi syariah. Transaksi syariah berasaskan pada lima prinsip utama yakni persaudaraan, keadilan, kemaslahatan, keseimbangan dan universalisme (IAI, 2016). Transaksi penyaluran dana di bank syariah atau lebih dikenal dengan istilah pembiayaan dapat dikatakan patuh terhadap prinsip syariah jika memenuhi kelima unsur tersebut.

Penelitian yang dilakukan oleh Triyanta (2009) menghasilkan temuan bahwa kepatuhan bank syariah terhadap prinsip hukum islam sangat ditentukan oleh pengawasan yang komprehensif oleh DPS maupun DSN. Dalam hasil penelitiannya juga disebutkan bahwa beberapa produk bank syariah yang ditawarkan saat ini masih dipertanyakan kehalalannya.

Penelitian yang dilakukan oleh Sukardi (2012) menghasilkan temuan bahwa terdapat ketidakpatuhan terhadap prinsip syariah dalam praktik penyaluran dana oleh bank syariah menggunakan akad murabahah. Bentuk ketidakpatuhan tersebut terdapat pada angsuran yang terikat dengan jangka waktu pelunasan (time value of money). Dalam prinsip syariah, ketika kesepakatan harga, termasuk jumlah angsuran, telah disepakati di awal akad maka jumlah angsuran tidak boleh berubah (DSN-MUI, 2017). 
Penelitian yang dilakukan oleh Lathif (2013) menghasilkan temuan bahwa praktik murabahah yang dilakukan oleh bank syariah cenderung mengutamakan pertimbangan efektivitas prosedur dan pertimbangan efisiensi waktu sehingga prinsip murabahah yang ideal dalam fikih muamalat sengaja dihindari. Pertimbangan-pertimbangan tersebut dipilih karena alasan memberikan kemudahan kepada nasabah.

Penelitian yang dilakukan oleh Ahmed (2014) menghasilkan temuan bahwa kegiatan operasional dan produk yang ditawarkan oleh bank syariah menuai banyak kritikan karena lemah dalam memenuhi prinsip syariah. Beberapa akad sengaja dibuat dengan tujuan untuk mendapatkan keuntungan dan akad tersebut mirip dengan transaksi yang dipraktikan oleh bank konvensional.

Dari penelitian terdahulu yang disebutkan di atas dapat diketahui bahwa masih ada bank syariah yang tidak patuh terhadap prinsip syariah dalam penyaluran dana termasuk pembiayaan dengan akad murabahah. Oleh sebab itu, penelitian ini dilakukan untuk membuktikan apakah bank syariah (BSM Cabang Ternate) secara operasional telah mematuhi prinsip syariah dalam praktik penyaluran dana bank khususnya pada pembiayaan dengan akad murabahah.

\section{METODE}

Metode kualitatif digunakan dalam penelitian ini. Pengumpulan data menggunakan teknik triangulasi sumber, yaitu cara pengumpulan data dari beberapa sumber dengan teknik yang sama (Sugiyono, 2015). Data primer diperoleh melalui wawancara mendalam dengan informan representatif dari pihak bank dan pihak nasabah. Informan utama dari pihak bank yakni orang yang memiliki kapasitas untuk menyetujui pencairan pembiayaan sedangkan informan pendukung dari pihak nasabah yakni nasabah yang memiliki kerjasama pembiayaan dengan bank syariah khususnya pembiayaan dengan akad murabahah. Selain itu, data sekunder diperoleh melalui telaah dokumen UU Nomor 21 Tahun 2008, fatwa DSN-MUI, Peraturan Bank Indonesia dan Otoritas Jasa Keuangan tentang kepatuhan operasional bank dan aturanaturan terkait lainnya.

Jenis wawancara yang digunakan dalam penelitian ini yaitu wawancara semi terstruktur. Jenis wawancara ini paling umum digunakan dalam tipe penelitian kualitatif (Qu \& Dumay, 2011). Teknik wawancara ini dimulai dengan menyiapkan pertanyaan terlebih dahulu sebelum wawancara dilakukan. Pertanyaan tersebut didasarkan pada tema yang dirancang untuk memperoleh respon dari narasumber secara terarah dan terperinci.

Proses analisis data dalam penelitian ini menggunakan model interaktif yang terdiri dari empat aktivitas utama yaitu mengumpulkan data, 
mereduksi data, menyajikan data, dan menarik suatu kesimpulan (Miles \& Huberman, 1994). Empat aktivitas tersebut dilakukan secara interaktif baik sebelum, sedang maupun setelah proses pengumpulan data sampai suatu data dianggap kredibel (Sugiyono, 2015).

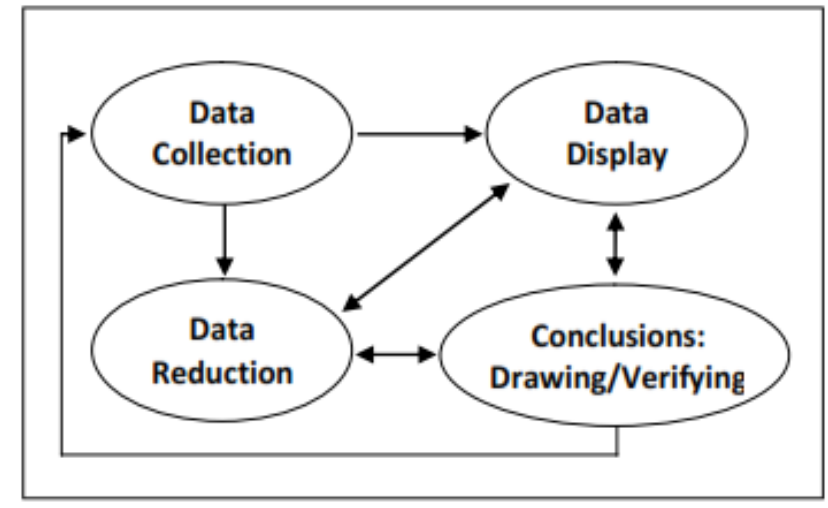

Gambar 1. Model Analisis Data

Sumber: Miles \& Huberman (1994)

\section{HASIL DAN PEMBAHASAN}

Hasil telaah dokumen terkait kepatuhan operasional bank yang dipraktikan di BSM menunjukan bahwa bank tersebut telah memenuhi prinsip syariah. Hal tersebut dapat dilihat dari; pertama, opini dewan pengawas syariah menyatakan secara umum bahwa pelaksanaan kegiatan operasional dan produk yang ditawarkan oleh BSM telah memenuhi prinsip syariah yang mengikuti fatwa DSN-MUI (BSM, 2019).

DPS BSM telah melakukan 13 kali uji petik selama tahun 2019 yang dimaksudkan untuk mengetahui kualitas dari pelaksanaan pemenuhan prinsip syariah pada praktik penyaluran dana oleh BSM. Fokus pengujian DPS BSM yaitu pada pemenuhan aspek syariah seperti kesesuaian akad yang digunakan dan terpenuhinya unsur-unsur akad pada suatu skema pembiayaan. Pengujian sampel dilakukan pada 16 lokasi di tahun 2019 dengan salah satu konsentrasi pengujian adalah pembiayaan dengan dasar akad murabahah (BSM, 2019).

Penilaian self assessment pelaksanaan Good Coorporate Governance BSM oleh OJK pada tahun 2019 semester 1 dan 2 memperoleh predikat sangat baik. Artinya produk yang ditawarkan BSM telah memenuhi aspek syariah sebagaimana yang direkomendasikan oleh DPS BSM yang sesuai dengan fatwa DSN-MUI. Selain itu, standar operasional prosedur BSM terkait pemenuhan aspek syariah pada kegiatan operasionalnya sudah lengkap dan memadai (BSM, 2019).

Hasil wawancara dengan mantan retail banking relationship manager BSM Cabang Ternate yang sekarang ditugaskan sebagai branch manager 
Kantor Cabang Pembantu (KCP) Bacan, beliau mengatakan bahwa proses pembiayaan dimulai ketika nasabah datang ke bank untuk menyampaikan maksud dan kebutuhannya. Pihak bank kemudian akan menentukan akad apa yang digunakan setelah mengetahui tujuan nasabah. Berikut rekapan wawancaranya:

"Akad ditentukan berdasarkan tujuan nasabah yang ditanyakan oleh pihak bank. Jika tujuannya jual beli maka kita akan mengarahkan ke akad murabahah. Setelah itu didiskusikan berapa margin yang akan ditetapkan dan berapa lama jangka waktu pelunasannya. Ketiga aspek ini (tujuan, margin dan jangka waktu pelunasan) harus disepakati antara nasabah dan kami. Setelah bersepakat baru kemudian kami proses, kemudian kami terbitkan akad-akad produk. Itulah proses pembiayaan yang selama ini dipraktikan di BSM Ternate"

Pernyataan tersebut sejalan dengan definisi murabahah dalam standar syariah nomor 8 AAOFI, Peraturan Bank Indonesia Nomor 9 Tahun 2007, buku standar produk murabahah OJK, dan Fatwa DSN-MUI Nomor 111 Tahun 2017, yaitu transaksi jual beli suatu barang dimana penjual menginformasikan harga perolehan ditambah margin kepada calon pembeli kemudian disepakati jumlah harga jual oleh kedua belah pihak (AAOFI, 2015; BI, 2007; DSN-MUI, 2017; OJK, 2016).

Meskipun hasil uji petik yang dilakukan oleh DPS BSM dan penilaian OJK terhadap kualitas pemenuhan prinsip syariah dalam kegiatan operasional BSM secara nasional menyatakan bahwa produk yang ditawarkan BSM telah sesuai dengan prinsip syariah yang ditetapkan oleh DSN-MUI tetapi pada praktiknya, di BSM cabang Ternate, pembiayaan dengan akad murabahah sering dikombinasikan dengan akad wakalah. Hasil wawancara dengan mantan retail banking relationship manager BSM Cabang Ternate yang sekarang ditugaskan sebagai branch manager BSM KCP Bacan, beliau mengatakan bahwa proses pendelegasian wewenang (akad wakalah) ini dilakukan bersamaan dengan akad murabahah. Setelah terjadi kesepakatan pembiayaan dengan akad murabahah antara bank dan nasabah untuk memenuhi kebutuhan nasabah maka bank kemudian mendelegasikan wewenangnya sekaligus menyerahkan uang kepada nasabah untuk memenuhi kebutuhannya tersebut menggunakan akad wakalah. Berikut rekapan wawancaranya:

"Biasanya satu akad itu ada akad turunannya. Kalau dia (nasabah) tujuannya untuk beli barang maka akad murabahah satu paket dengan akad wakalah untuk perwakilan. Bank mewakilkan ke nasabah untuk membelanjakan barangnya sesuai dengan kebutuhan nasabah. Itu akad wakalah. Bank sudah percaya dengan nasabah untuk membeli barang sesuai dengan kebutuhan. ...karena selama ini bank belum memiliki toko 
untuk memenuhi kebutuhan nasabah sehingga muncullah akad wakalah ini sehingga nasabah yang belanja barang sendiri".

Akad wakalah digunakan untuk memberikan kesempatan kepada nasabah agar nasabah dapat membelanjakan barang sesuai kebutuhannya dengan alasan bank syariah tidak memiliki stok persediaan yang dapat memenuhi kebutuhan nasabah. Tujuan akad ini adalah pendelegasian wewenang bank syariah kepada nasabah untuk melakukan kewajiban bank sebagai penjual yakni menyediakan stok barang. Pada prinsipnya praktik pembiayaan dengan akad murabahah di bank syariah yang dikombinasikan dengan akad wakalah dapat dilakukan jika akad wakalah telah selesai ditunaikan dan barang yang hendak dijadikan objek dalam akad murabahah sudah menjadi milik bank syariah secara prinsip (DSN-MUI, 2000).

Praktik pembiayaan dengan akad murabahah sebagaimana dinyatakan oleh narasumber di atas berbeda dengan putusan fatwa DSN-MUI No.4 Tahun 2000 tentang murabahah. Dalam fatwa tersebut disebutkan bahwa jika bank syariah hendak mewakilkan pembelian barang dari pihak ketiga kepada nasabah maka akad jual beli murabahah wajib dilakukan setelah barang menjadi milik bank secara prinsip. Artinya akad wakalah tidak dapat disepakati secara bersamaan dengan akad murabahah. Akad murabahah hanya dapat disepakati setelah akad wakalah selesai ditunaikan dan barang yang akan diperjualbelikan sudah menjadi hak penjual secara penuh.

Jika akad murabahah disepakati sebelum akad wakalah selesai ditunaikan maka pola transaksi seperti ini memungkinkan akad jual-beli murabahah disepakati tanpa adanya barang yang dipertukarkan (underlying asset) sehingga satu-satunya barang yang menjadi dasar pertukaran akad ini adalah uang. Praktik seperti ini jelas bertentangan dengan prinsip syariah dimana alat tukar dilarang untuk dijadikan komoditas. Praktik yang demikian tidak ada bedanya dengan pembiayaan di bank konvensional dimana bank hanya bertindak sebagai penyedia dana dan bukan sebagai penjual yang memiliki barang. Hasil penelitian ini sama dengan penelitian Lathif (2013) yang membuktikan bahwa jenis pembiayaan murabahah yang paling sering digunakan di bank syariah adalah pembiayaan dengan akad murabahah yang dikombinasikan dengan akad wakalah. Jenis pembiayaan murabahah seperti ini sengaja dipilih untuk digunakan oleh sebagian besar bank syariah padahal pembiayaan jenis ini tidak ideal dalam konteks fikih muamalat (Lathif, 2013).

Hasil wawancara dengan salah satu nasabah bank syariah yang saat ini sementara mendapatkan pembiayaan dari bank syariah guna merenovasi rumah tempat tinggalnya, beliau mengatakan bahwa proses untuk mendapatkan pembiayaan di bank syariah kurang lebih sama dengan apa yang telah disampaikan oleh narasumber sebelumnya. Berikut rekapan wawancaranya: 
"Proses mendapatkan pembiayaan dari bank syariah ini berawal dari saya datang ke bank syariah tentu dengan niat untuk mendapatkan pinjaman untuk merenovasi rumah. Setelah bertemu dan mengutarakan maksud saya kepada bagian yang menangani pembiayaan, kami kemudian bersepakat untuk memenuhi kebutuhan saya dengan akad murabahah. Setelah tanda tangan kesepatakan, uang ditransfer ke rekening saya dan saya yang membelanjakan bahan-bahan yang dibutuhkan untuk merenovasi rumah".

Pernyataan tersebut menegaskan bahwa proses pembiayaan dengan akad murabahah dimana bank mewakilkan tanggungjawabnya kepada nasabah untuk membeli kebutuhnnya. Proses ini sekilas sama dengan apa yang tertuang dalam aturan transaksi syariah baik fatwa DSN-MUI tentang murabahah maupun aturan lainnya. Akan tetapi setelah selesai membeli kebutuhannya, nasabah tidak memberikan laporan atau menyampaikan bukti pembelian kepada bank sehingga bank tidak mengetahui jenis barang apa saja yang telah dibeli oleh nasabah. Berikut rekapan hasil wawancara dengan nasabah yang sama:

"Setelah saya selesai membeli barang, saya tidak pernah menyampaikan nota-nota pembelian itu ke bank".

Pernyataan tersebut sama dengan pernyataan narasumber pertama:

"harusnya setelah belanja, nota belanjaan itu harus disampaikan atau diserahkan ke pihak bank, namun selama ini belum dilakukan karena berbagai alasan. Kadang nasabah mengatakan lupa, notanya sudah tidak tahu dimana. Itu yang selama ini belum jalan".

Pernyataan para narasumber ini membuktikan bahwa Bank Syariah Mandiri Cabang Ternate tidak konsisten dalam mengaplikasikan akad murabahah yang dikombinasikan dengan akad wakalah karena nasabah membeli barang atas nama dirinya bukan atas nama bank. Nasabah membeli barang ke pihak ketiga tanpa harus menyampaikan apa yang dibelinya kepada bank. Hal ini jelas bertentangan dengan prinsip syariah karena bank menjual barang yang belum menjadi miliknya secara prinsip. Selain itu, bank juga tidak dapat memastikan kejelasan dan kehalalan barang yang dibelanjakan oleh nasabah padahal dalam salah satu asas transkasi syariah yakni asas keadilan, dilarang adanya unsur ketidakjelasan (gharar), haram, dalam suatu transaksi.

Selain unsur gharar dan haram, unsur maysir (sikap spekulatif) juga bepontensi muncul dalam dalam pembiayaan dengan akad murabahah sebagaimana yang dijelaskan oleh narasumber di atas. Potensi munculnya unsur maysir ini karena kontrol terhadap barang yang dibeli nasabah tidak 
dilakukan oleh pihak bank. Bank tidak dapat melakukan kontrol terhadap barang yang dibeli nasabah karena tidak ada laporan pembelian dari nasabah. Selain laporan pembelian barang dari nasabah, bank mestinya dapat melakukan kontrol terhadap pembelian barang oleh nasabah dengan memanfaatkan kehadiran dewan pengawas syariah tetapi menurut narasumber kedua, tidak ada dari pihak bank yang mengkonfirmasi kepadanya terkait kualitas halal dari barang-barang yang dibelinya.

Hasil penelitian ini sejalan dengan penelitian yang dilakukan oleh Mukhibad (2018), Sikrillah (2018) bahwa kualitas halal suatu produk bank syariah sangat ditentukan oleh pengawasan dewan pengawas syariah secara komprehensif. Pengawasan yang belum dilakukan oleh dewan pengawas syariah BSM termasuk BSM cabang Ternate pada barang yang dibelanjakan oleh nasabah menjadikan kualitas halal dari akad murabahah yang digunakan dipertanyakan kehalalannya. Hasil penelitian ini juga sejalan dengan penelitian yang dilakukan oleh Ahmed (2014); Lathif (2013); dan Sukardi (2012) bahwa pemenuhan prinsip syariah dalam akad murabahah di bank syariah masih lemah karena bank syariah cenderung lebih mengutamakan pertimbangan efektivitas prosedur dan efisiensi waktu dibandingkan dengan prinsip-prinsip murabahah yang ideal sebagaimana prinsip akad murabahah dalam kaidah fikih muamalat.

\section{KESIMPULAN}

Pada pembiayaan dengan akad murabahah di BSM Cabang Ternate, Dewan Pengawas Syariah belum melakukan kontrol sampai pada apa yang dibelanjakan oleh nasabah. Nasabah juga tidak melaporkan apa yang telah dibelanjakan sehingga bank tidak dapat menilai kualitas halal dari barang yang dibelanjakan. Oleh sebab itu asas keadilan dalam transaksi dengan akad ini tidak dapat terpenuhi. Tidak terpenuhinya asas keadilan ini mengindikasikan bahwa terdapat ketidakpastian (halal atau haram) dan ketidakjelasan (gharar) barang yang dibelanjakan oleh nasabah. Praktik pembiayaan dengan akad murabahah yang dilakukan BSM Cabang Ternate saat ini secara aturan telah memenuhi asas transaksi syariah tetapi pada praktiknya masih abai terhadap substansi dari akad yang digunakan. Akad murabahah yang disepakati bersamaan dengan akad wakalah jelas melanggar prinsip syariah karena sebagai penjual, bank syariah diwajibkan memiliki barang secara hak sebelum dijual kepada pembeli (nasabah). Akad murabahah seharusnya dapat disepakati setelah akad wakalah selesai ditunaikan dan objek murabahah sudah menjadi milik bank secara prinsip. Dengan alasan kemudahan transaksi, BSM Cabang Ternate telah 
mengabaikan prinsip syariah yang harusnya dipenuhi dalam akad murabahah.

\section{DAFTAR PUSTAKA}

AAOFI. (2015). Shari'ah Standards: Full Text of Shari'ah Standards for Islamic Financial Institutions. Manama: The Accounting and Auditing Organization for Islamic Financial Institutions.

Ahmed, H. (2014). Islamic Banking and Shari'ah Compliance: A Product Development Perspective. Journal of Islamic Finance, Vol. 3(No. 2), h. 1529. https://doi.org/10.12816/0025102

Anshori, A. G. (2018). Hukum perjanjian Islam di Indonesia: konsep, regulasi, dan implementasi. UGM PRESS.

Bank Indonesia. (2007). Peraturan Bank Indonesia Nomor 9/19/PBI/2007 Tentang Pelaksanaan Prinsip Syariah dalam Kegiatan Penghimpunan Dana dan Penyaluran Dana serta Pelayanan Jasa Bank Syariah.

Bank Indonesia. (2020). Laporan Perekonomian Provinsi Maluku Utara Februari 2020 - Bank Sentral Republik Indonesia.

https://www.bi.go.id/id/publikasi/kajian-ekonomi-regional/malut/ Pages/Laporan-Perekonomian-Provinsi-Maluku-Utara-Februari2020.aspx

Bank Muamalat Indonesia. (2019). Annual Report PT. Bank Muamalat Indonesia Tbk. Transformasi untuk Pertumbuhan Bisnis yang Berkelanjutan.

Bank Syariah Mandiri. (2019). Annual Report PT. Bank Syariah Mandiri Tbk. Memberikan Nilai Tambah Melalui Pengembangan Kapabilitas Internal.

DSN-MUI. (2000). Fatwa Dewan Syariah Nasional No. 04/DSN-MUI/IV/2000 tentang Murabahah (Issue 4). https://drive.google.com/file/d/0BxTlINihFyzdVVoTElXWEdZSFk/view

DSN-MUI. (2017). Fatwa Dewan Syariah Nasional No. 111/DSN-MUI/IX/2017 tentang Akad Jual Beli Murabahah (Issue 9). https://drive.google.com/file/d/1PJqKTaew1MoSsxlJpXnblz5x2DKhSlf q/view

Ekawati, K., \& Shofawati, A. (2019). Faktor-Faktor Yang Mempengaruhi Tingkat Margin Murabahah Pada Industri Perbankan Syariah Periode 2012-2017. Jurnal Ekonomi Dan Bisnis Islam (Journal of Islamic Economics and Business), 5(1), 50.

https://doi.org/10.20473/jebis.v5i1.10901

Fauzia, I. Y. (2018). Perilaku Pebisnis dan Wirausaha Muslin dalam Menjalankan Asas Transaksi Syariah. Jurnal Akuntansi Multiparadigma, 9(1), 38-56. http://dx.doi.org/10.18202/jamal.2018.04.9003

Hakim, L., \& Anwar, A. (2017). Pembiayaan Murabahah Pada Perbankan Syariah dalam Perspektif Hukum di Indonesia. Al-Urban: Jurnal Ekonomi Syariah Dan Filantropi Islam, 1(2), 212-223.

Harahap, S. S., Wiroso, \& Yusuf, M. (2010). Akuntansi Perbankan Syariah (Cetakan IV). Jakarta: LPFE Usakti.

Ikatan Akuntan Indonesia. (2016). Standar Akuntansi Keuangan Syariah. 
Jakarta: Ikatan Akuntan Indonesia.

Indonesia, P. R. (2008). Undang-Undang Republik Indonesia Nomor 21 Tahun 2008 Tentang Perbankan Syariah.

Ilmi, F. (2020). Implementasi Asas Kesetaraan dalam Akad Pembiayaan Murabahah pada KPR-BTN IB di BTN Syariah Cabang Banjarmasin. Shar-E: Jurnal Kajian Ekonomi Hukum Syariah, 6(2), 53-68. https://doi.org/10.37567/shar-e.v6i2.129

Iqbal, Z., \& Mirakhor, A. (2011). An Introduction to Islamic Finance: Theory and Practice (Second). Singapore: John Wiley \& Sons (Asia) Pte. Ltd. https://doi.org/10.1002/9781118390474

Kusuma, T. (2020). Cryptocurrency dalam Perdagangan Berjangka Komoditi di Indonesia Perspektif Hukum Islam. Tsaqafah, Vol. 16(No. 1), h. 109126. https://doi.org/10.21111/tsaqafah.v16i1.3663

Lathif, A. A. (2013). Konsep dan Aplikasi Akad Murabahah pada Perbankan Syariah di Indonesia. AHKAM : Jurnal Ilmu Syariah, Vol. 12(No. 2), h 6978. https://doi.org/10.15408/ajis.v12i2.967

Lestari, D. V., \& Purbasari, I. (2019). Pemenuhan Prinsip Syariah dalam Kriteria Penerbitan Efek Syariah di Indonesia dan Malaysia. Jurnal Simposium Hukum Indonesia, 1(1), 707-725.

Malik, M., Malik, A., \& Mustafa, W. (2011). Controversies that make Islamic banking controversial: An analysis of issues and challenges. American Journal of Social and Management Sciences, Vol. 2(No. 1), h. 41-46. https://doi.org/10.5251/ajsms.2011.2.1.41.46

Mardian, S. (2015). Tingkat Kepatuhan Syariah di Lembaga Keuangan Syariah. Jurnal Akuntansi Dan Keuangan Islam, Vol. 3(No. 1), h. 57-68. http://jurnal.sebi.ac.id/index.php/jaki/article/view/46

Maulana, D. F., \& Rozak, A. (2021). Ketetapan Hukum Dan Rekonstruksi Parameter Hilah Pada Praktik Perbankan Syariah. Bilancia, 15(1), 2750

Miles, M. B., \& Huberman, A. M. (1994). An Expanded Sourcebook Qualitative Data Analysis (2nd Editio). California: SAGE Publication.

Mukhibad, H. (2018). Peran Dewan Pengawas Syariah Dalam Pengungkapan Islamic Sosial Reporting. Jurnal Akuntansi Multiparadigma, 9(2), 299311. https://doi.org/10.18202/jamal.2018.04.9018

Nurdin, R., \& Jariah, S. A. (2021). Analisis Rate Margin Murabahah Pada Transaksi Jual Beli Rumah Subsidi Kpr Btn Syariah Dalam Perspektif Hukum Islam (Suatu Penelitian Pada BTN Syariah KC Banda Aceh). Jurnal Al-Mudharabah, 3(1), 27-40.

Otoritas Jasa Keuangan. (2016). Standar Produk Perbankan Syariah Murabahah. Jakarta: Otoritas Jasa Keuangan.

Otoritas Jasa Keuangan. (2019). Laporan Perkembangan Keuangan Syariah Indonesia 2018. https://www.ojk.go.id/id/kanal/syariah/data-danstatistik/laporan-perkembangan-keuangan-syariahindonesia/Pages/2018.aspx

Pardiansyah, E. (2017). Investasi dalam Perspektif Ekonomi Islam: Pendekatan Teoritis dan Empiris. Economica: Jurnal Ekonomi Islam, 8(2), 337-373. https://doi.org/10.21580/economica.2017.8.2.1920 
Prabowo, B. A. (2009). Konsep Akad Murabahah Pada Perbankan Syariah (Analisa Kritis Terhadap Aplikasi Konsep Akad Murabahah di Indonesia dan Malaysia). Ius Quia Iustum Law Journal, Vol. 16(No. 1), h. 106-126. https://doi.org/10.20885/iustum.vol16.iss1.art7

Qu, S. Q., \& Dumay, J. (2011). The Qualitative Research Interview. Qualitative Research in Accounting and Management, Vol. 8(No. 3), h. 238-264. https://doi.org/10.1108/11766091111162070

Rahmayati, R. (2018). Strategi Perbankan Syariah Sebagai Solusi Pengembangan Halal Industry di Indonesia. AT-TAWASSUTH: Jurnal Ekonomi Islam, 1(1), 314. https://doi.org/10.30821/ajei.v1i1.2746

Rohmaniyah, W. (2019). Fiqih Muamalah Kontemporer (Vol. 129). Duta Media Publishing.

Sikrillah, L. S. (2018). Analisis Penetapan Harga Jual Pembiayaan Murabahah pada Lembaga Keuangan Syariah Bank dan Non Bank. El Dinar, 4(2), 212. https://doi.org/10.18860/ed.v4i2.5463

Sugiyono. (2015). Metode Penelitian Kualitatif dan R and D. In Bandung: Alfabeta. Alfabet.

Sukardi, B. (2012). Kepatuhan Syariah (Shariah Compliance) dan Inovasi Produk Bank Syariah di Indonesia. Akademika: Jurnal Pemikiran Islam, Vol. 17(No. 2), h. 235-252. http://ejournal.metrouniv.ac.id/index.php/ akademika/article/view/201

Wahyuni, E. (2018). Satanic Finance Dalam Perbankan Syariah. Iltizam Journal of Sharia Economic Research, 2(1), 20. https://doi.org/10.30631/iltizam.v2i1.109

Zakiy, F. S., \& Athief, F. H.N. (2015). Metode Perhitungan Penentuan Harga Jual pada Pembiayaan Murabahah di Perbankan Syariah. Jurnal El Dinar, 3(1), 1-11. 